\title{
IMPLEMENTASI BLENDED LEARNING DALAM \\ MATA KULIAH ULUMUL QUR'AN PADA \\ PASCASARJANA UNIVERSITAS ISLAM NEGERI \\ ALAUDDIN MAKASSAR
}

\author{
Achmad Abubakar \\ Universitas Islam Negeri Alauddin Makassar \\ achmad.abubakar@uin-alauddin.ac.id \\ Ahmad Yani \\ Universitas Islam Negeri Alauddin Makassar \\ ahmadyani@uin-alauddin.ac.id \\ Abdul Syatar \\ Universitas Islam Negeri Alauddin Makassar \\ abdul.syatar@uin-alauddin.ac.id
}

A bstract

This study aims to see the implementation of blended learning in Ulumul Qur'an courses at UIN Alauddin $M$ akassar Postgraduate. The method used in this study uses a type of qualitative research related to the implementation of Blended Learning Courses Ulumul Qur'an at the Postgraduate UIN A lauddin M akassar. The results showed that: (1) the description of the model of implementation of the implementation of the study blended Ulumul Qur'an courses at the Postgraduate UIN A lauddin M akassar using a dual-system that is a combination of conventional systems with online. M ore use of online learning systems during the Pandemic (80\%) compared to traditional faceto-face learning systems. The merger of the two systems includes the incorporation of learning resources as well (learning modules, textbooks, and journals), the implementation of learning (online discussions, watching videos, and accessing supporting resources, and the incorporation of a learning evaluation system, including standardized assessment through quizzing, midterm 
exams, and final exams. (2) the results of the implementation of blended learning in Ulumul Qur'an courses are illustrated from five main aspects, namely (a) increased utilization of various sources, (b) increased active participation, (c) increased ability to construct knowledge, (d) activation of feedback, and (e) improvement of academic achievement. Keywords: Bleanded Learning; U lumul Qur'an; Graduate.

\section{A bstrak}

Penelitian ini bertujuan untuk melihat implementasi blended learning dalam mata kuliah Ulumul Qur'an pada Pascasarjana UIN Alauddin Makassar. Metode yang digunakan dalam penelitian ini menggunakan jenis penelitian lapangan (qualitative research) yang berkaitan dengan implementasi pembelajaran Blended Learning Mata Kuliah Ulumul Qur'an pada Pascasarjana UIN A lauddin Makassar. Hasil penelitian menunjukkan bahwa: (1) gambaran model pelaksanaan pembelajaran blended mata kuliah Ulumul Qur'an pada Pascasarjana UIN Alauddin Makassar menggunakan dual-system yakni perpaduan antara sistem konvensional dengan daring. Penggunaan sistem pembelajaran daring selama masa Pandemi lebih banyak (80\%) dibandingkan dengan sistem pembelajaran tradisional tatap muka. Penggabungan dua sistem mencakup penggabungan sumber belajar juga (modul pembelajaran, buku teks, dan jurnal), pelaksanaan pembelajaran (diskusi online, menonton video, dan mengakses sumber pendukung, dan penggabungan sistem evaluasi pembelajaran, mencakup penilaian standar melalui pemberian kuis, ujian tengah semester, dan ujian akhir. (2) hasil implementasi pembelajaran blended pada mata kuliah Ulumul Qur'an tergambar dari lima aspek utama, yaitu (a) peningkatan pemanfaatan aneka sumber, (b) peningkatan partisipasi aktif, (c) peningkatan kemampuan untuk mengonstruksi pengetahuan, (d) pengaktifan umpan balik, dan (e) peningkatan prestasi akademik.

K ata kunci: Bleanded L earning; Ulumul Qur'an; Pascasarjana. 


\section{PENDAHULUAN}

Era baru dalam dunia pendidikan telah memperkenalkanreformasi pendidikan yang berkaitan erat dengan pengintegrasian Information Comunication Technologi (ICT) yang terimplementasi sebagai sarana komunikasi untuk meningkatkan kinerja dunia pendidikan itu sendiri secara signifikan. Informasi merupakan sumber utama yang dibutuhkan bagi hampir semua masyarakat. Saat ini, teknologi informasi telah berperan penting sebagai media informasi dan komunikasi dalam berbagai bidang kehidupan termasuk bidang pendidikan.

Dunia pendidikan termasuk yang paling diuntungkan dari kemajuan ICT karena memperoleh manfaat yang luar biasa. Dari eksplorasi sumber belajar berkualitas seperti literatur, jurnal, dan buku, membangun forum-forum diskusi ilmiah, sampai konsultasi/diskusi dengan para pakar/ahli di dunia. Semua itu dapat dilakukan dengan mudah tanpa adanya batas karena setiap individu dapat melakukannya sendiri. Dampak yang sedemikian Iuas tersebut telah memberikan warna atau wajah baru dalam sistem pendidikan di dunia ini. Hal ini dibuktikan dengan banyaknya pengembangan model-model pembelajaran yang mengacu pada pembelajaran berbasis teknologi informasi.

Seiring dengan perkembangan ICT tersebut, manusia dihadapkan pada tantangan sekaligus peluang untuk dapat memanfaatkan dan mengakses informasi secara cepat. perkembangan ICT yang sejak kemunculannya pertama kali telah mengalami perubahan yang sangat pesat dan signifikansinya sangan dirasakan dalam berbagai bidang kehidupan di antaranya bidang ekonomi, keuangan termasuk bidang pendidikan khusunya pembelajaran.

Kehadiran sistem ICT berbasis online dan pemanfaatan teknologi komputer dengan kemampuan dan akselerasinya, memungkinkan pengembangan sistem pembelajaran yang efektif dan efisien. Dengan memanfaatkan teknologi komputer, didapat manfaat berupa kemudahan menyimpan, mengorganisasi dan melakukan pengambilan terhadap berbagai data yang dapat dijangkau secara cepat dan mudah oleh pebelajar.

Kemajuan teknologi ini kemudian menawarkan banyak kemudahan pada berbagai aspek kehidupan, mulai dari kebutuhan pribadi sampai kegiatan bisnis. Bahkan lebih jauh lagi, akhir-akhir ini teknologi informasi telah menjadi salah satu faktor yang sangat berpengaruh pada keberhasilan suatu organisasi dan penggunaannya dapat dijadikan sebagai suatu strategi dalam menjaga kepercayaan dari para penggunanya, termasuk juga dalam lembaga pendidikan khususnya Perguruan Tinggi dan faktor yang paling dominan pengaruhnya terhadap keberhasilan 
lembaga pendidikan adalah proses pembelajaran, di mana pembalajaran dalam hal ini adalah aktivitas proses belajar mengajar yang dilakukan oleh tenaga pendidik. Oleh karena itu dalam menunjang pelaksanaan pembelajaran maka sangatlah ditentukan oleh model atau desain pembelajaran yang akan digunakan dalam proses pembelajaran. ${ }^{1}$

Dengan semakin meningkatnya kecepatan arus informasi akibat globalisasi, peranan teknologi informasi menjadi vital dan sangat menentukan bagi sebuah lembaga pendidikan dalam meningkatkan kemampuannya menghadapi persaingan dan mampu memberikan pelayanan yang memuaskan bagi peserta didik, termasuk di dalamnya pemanfaatan media siaran televisi, radio, dan surat kabar menjadi bagian yang menarik untuk meningkatkan prestasi belajar peserta didik. ${ }^{2}$ Bahkan pemanfaatan sumber belajar online seperti penggunaan T eknologi Informasi dan Komunikasi (TIK) secara fundamental mengubah pola interaksi peserta didik dan pendidik, proses pembelajaran, dan hasil belajar. ${ }^{3}$ Sumber-sumber belajar digital juga berkontribusi positif dalam memberi percepatan pengembangan sistem pembelajaran dan memberi inovasi baru dalam penggunaan metode penyajian baik dalam setting ruang kelas tradisional maupun pada pembelajaran online. 4 Pemanfaatan web-blog dalam pembelajaran dipandang sebagai media yang sangat efektif dalam interaksi yang dibangun di luar kelas tradisional, bahkan dapat meningkatkan pengetahuan serta mendukung terciptanya suasana belajar yang menyenangkan. ${ }^{5}$ B eberapa jenis pembelajaran telah

1 Muhammad Yaumi and Muljono Damopolii, "Desain Blended Learning: Model Pemaduan Sumber Belajar Online Dan Tradisional," in Konferensi Nasional Ke- 6 A sosiasi Program Pascasarjana Perguruan Tinggi M uhammadiyah 'A isyiyah (Y ogyakarta: Program Pascasarjana Universitas M uhammadiyah Y ogyakarta, 2017), 135-145, http://repositori.uinalauddin.ac.id/14929/.

2 Nurdin Ibrahim, "Hubungan A ntara Belajar M andiri Dan M otivasi Berprestasi Dengan Hasil B elajar Pendidikan A gama Islam Di SM P T erbuka," Lentera Pendidikan 15, no. 1 (2012): 1-17.

3 Frank Rennie, "The Use of Flexible Learning Resources for Geographically Distributed Rural Students," Journal of Distance Education 24, no. 1 (2003).

${ }^{4}$ Cecilia Manrique and Gabriel Manrique, "Leveraging Learning Resources: Social Networking, Online Teaching Utilities, Digital Media A nd The M odern Classroom Experience," International Journal of A rts \& Sciences 4, no. 21 (2011): 215-222.

5 Y.-M. LinM. Van't Hooft, "The Impact of Blogs on Student Perceptions toward Social Interaction and Learning Satisfaction in Blended 
dikembangkan dalam wangka mewujudkan pelayanan yang berkualitas salah satunya pembelajaran yang dikembangkan dengan pembelajaran yang berbasis daring selama covid-19 yang telah dirancang berdasarkan kebutuhan pebelajar. ${ }^{6}$

Universitas Islam Negeri (UIN) Alauddin Makassar sebagai perguruan tinggi Islam terbesar di wilayah timur Indonesia seyogianya selalu secara terus-menerus meningkatkan kemampuan sumber daya manusia khusunya kemampuannya dibidang ICT, sehingga tercipta wawasan teknologi yang mendalam, kemampuan teknik dalam mengaplikasikan media dan teknologi yang diharapkan dapat mendukung diselenggarakannya pembelajaran daring untuk seluruh mahasiswa dan dosen di lingkungan UIN Alauddin Makasar khususnya di masa pendemik Covid 19 saat ini.

A walnya pelaksanaan perkuliahan di Pascasarjana dilakukan secara konvensional (face to face) saja tanpa ada kegiatan tambahan lain termasuk dalam pengelolaan sumber belajar. Meningat kondisi saat ini yang tidak memungkinkan untuk melakukan pertemuan secara langsung kelompok besar, dan saat ini di UIN telah tersedia fasilitas yang menunjang pelaksanaan pembelajaran secara daring. $\mathrm{H}$ al inilah yang mendasari sehingga penting untuk mengembangkan model pembelajaran blended berbantukan weblog yang dipadu dengan peralatan online lainnya dikembangkan untuk memfasilitasi pelaksanaan pembelajaran secara periodik di Pascasarjana. Dalam perkembangannya, pembelajaran blended semakin diminati oleh peserta didik baik. Itulah sebabnya weblog mata kuliah ulumul qur' an dirancang dan diimplemetasikan dengan memaksud untuk mewujudkan pembelajaran yang berbasis media dan teknologi termasuk berbagai aplikasi yang sesuai dengan kondisi real UIN A lauddin M akassar.

\section{M etode Penelitian}

Jenis penelitian adalah penelitian lapangan (qualitative research), Penelitian ini difokuskan Implementasi Blended L earning M ata K uliah U lumul Qur' an di Pascasarjana U niversitas Islam Negeri Alauddin Makassar. Menurut Lexi J. Moleong

Learning," International Conference on Computers in Education (2008): 833839, https://www.semanticscholar.org/paper/The-Impact-of-Blogs-onStudent-Perceptions-toward-L ina-

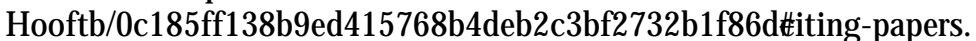

${ }^{6}$ Rahayu R etnaningsih, "E-L earning System Sebuah Solusi Pragmatis Program V okasional Semasa Pandemi COV ID-19," Jurnal Taman Vokasi 8, no. 1 (2020): 28-34. 
mengemukakan bahwa penelitian kualitatif adalah jenis penelitian yang bermaksud untuk memahami fenomena tentang apa yang dialami oleh subjek penelitian, seperti perilaku, motivasi, tindakan, dan lain-lain secara holistik serta dengan cara deskripsi dalam bentuk kata-kata dan bahasa pada suatu konteks khusus yang alamiah dan dengan memanfaatkan berbagai metode alamiah. ${ }^{7}$ Penelitian kualitatif merupakan metode-metode untuk mengekplorasi dan memahami makna yang oleh sejumlah individu atau sekelompok orang dianggap berasal dari masalah sosial atau kemanusiaan. ${ }^{8}$ L ebih lanjut dikemukakan ol eh D onald A ry bahwa penelitian kualitatif adalah qualitative researches seek to understand a phenomenom by focusing of the total picture rather than breaking it down in to variables. Penelitian ini termasuk katagori penelitian yang bersifat kualitatif deskriptif karena penelitian ini memberi gambaran tentang hasil penelitian yang mendeskripsikan data-data aktual yang diperoleh di lapangan. Data tersebut selanjutnya dielaborasi untuk dianalisis sehingga diharapkan dapat menjelaskan tentang penerapan pembelajaran blended learning dalam mata kuliah U lumul Q ur' an di Pascasarjana Universitas Islam Negeri (UIN) Alauddin Makassar.

Teknik pengumpulan data terdiri atas wawancara, observasi, studi dokumentasi. Wawancara digunakan untuk mendapatkan data dari informan dengan mekanisme yanng sesuai dengan peraturan pemerintah perihal pembatasan sosial skala besar maupun sosial dan physical distancing, sehingga dalam hal ini wawancara dilakukan secara tidak langsung yakni dengan melalui media baik secara langsung maupun dalam bentuk pertanyaan untuk dijawab yang diawali dengan permintaan persetujuan dari informan. Observasi digunakan untuk melengkapi data dari wawancara dan pengumpulan dokumentasi terkait dengan model dan metode yang digunakan serta ef ektivitas penerapan blended learning dalam rangka mendapatkan jawaban terhadap masalah penelitian, antara lain mengamati kelengkapan data dan sistem pembelajaran yang digunakan dalam kaitannya dengan pembelajaran blended learning pada mata kuliah Ulumul Qur'an di Pascasarjana UIN A lauddin M akassar.

7 Lexi J. Moleong, Metodologi Penelitian Kualitatif, XXVII. (B andung: Remada R osdakarya, 2010)., h. 14.

8 John W. Creswell, Research Design Pendekatan Kaulitatif, K uantitatif, Dan M ixed (Y ogyakarta: Pustaka Pelajar, 2009)., h. 202. 


\section{PEMBAHASAN}

\section{Model Pembelajaran Campuran Mata Kuliah Ulumul Qur'an}

Belajar dari berbagai kelemahan pelaksanaan pembelajaran dalam mata kuliah U lumul Qur' an, maka dipandang perlu untuk mengimplementasikan pembelajaran Ulumul Qur'an melalui web-blog, yang bertujuan untuk memudahkan mahasiswa belajar dan mengakses berbagai sumber belajar. Selain itu, dosen dapat melakukan pelacakan terhadap tulisan mahasiswa dengan mudah karena terjaring secara online di seluruh dunia.

Desain web-blog ini dikembangkan dengan mempertimbangkan konstruk tampilan, warna, aksesibiltas, bahasa, dan menu tampilan. Khusus untuk menu dipilih berdasarkan hasil pelacakan berbagai sumber belajar baik yang menggunakan weblog maupun website lain. Dari ramuan berbagai sumber tersebut, maka menu tampilan blog mencakup beranda, Modul, ebook, ejournal, RPS, Forum Diskusi, Video Pembelajaran, Kuis, UTS, dan UAS. Urutan itu penamaan tersebut dipertimbangkan berdasarkan lima aspek utama, yaitu (1) informasi umum tentang weblog yang termuat pada bagian beranda, (2) Rencana Pelaksanaan Pembelajaran, (3) Sumber Belajar, (4) Pelaksanaan Pembelajaran, dan (5) Evaluasi Pembelajaran.

Hasil observasi terhadap situs http://quranimedia.uinalauddin.ac.id/ kuliah ulumul Qur'an menunjukkan bahwa Informasi umum seperti tertuang dalam beranda weblog dimaksudkan untuk memberi informasi faktual tentang tujuan, berbagai kelemahan pembelajaran yang mengandalkan pertemuan tatap muka di satu sisi dan kelebihan pembelajaran blended dan pembelajaran jarak jauh di sisi lain. Selain itu, rencana pelaksanaan pembelajaran merupakan landasan dan pijakan dasar bagi dosen dan mahasiswa di dalam melaksanaan pembelajaran baik yang berkenaan dengan informasi pertemuan, kemampuan akhir yang diharapkan (learning objektives), materi pembelajaran, bentuk pembelajaran, maupun yang berkenaan dengan indikator dan bobot penilaian.

Sumber belajar juga merupakan bagian yang tak terpisahkan dengan weblog ini karena di dalamnya disediakan berbagai materi pembelajaran seperti yang terdapat dalam modul pembelajaran yang langsung dapat cari (searching) yang didahului dengan kata sandi mahasiswa untuk memberikan proteksi terhadap bahan ajar yang tersedia. Pembelajaran ulumul qur' an ini juga ditunjang dengan penggunaan buku dan jurnal elektronik yang tersedia secara gratis pada situs weblog. 
Dalam pelaksanaan pembelajaran, para pengguna (users) dalam hal ini dosen dan mahasiswa menyaksikan dan menelaah berbagai konsep yang tersedia di dalam video pembelajaran termasuk berbagai rekaman dari hasil pembelajaran sebelumnya yang dapat dikembangkan, dikoreksi, dan dianalisis oleh para mahasiswa. Selain, itu, dalam pelaksanaan pembelajaran juga disediakan forum diskusi online di mana dosen berperan untuk menyediakan materi diskusi dan mahasiswa membaca, mengaji, dan memberikan respon secara online. A dapun pelaksanaan pembelajaran tersebut dapat juga dilaksanakan secara tatap muka ketika pembelajaran berlangsung di dalam ruang kelas tradisional dengan memanfaatkan video secara offline dan juga diskusi dan presentasi yang bahan-bahannya merupakan pendalaman dari hasil diskusi online.

Setelah semua informasi yang terdapat di dalam beranda dipahami, rencana pelaksanaan pembelajaran diketahui, sumber belajar diakses dan dibaca, dan pelaksanaan pembelajaran dilakukan, maka dilanjutkan dengan suatu evaluasi pembelajaran yang berorientasi proses dan hasil. Berorientasi proses dengan memberikan kuis pada setiap kali pertemuan untuk mengukur kedalaman penguasaan konsep oleh para mahasiswa, yang dilanjutkan dengan Ujian Tengah Semester (UTS) untuk mengukur dan menilai sejauh mana teori dan konsep yang sudah dipelajari selama beberapa kali pertemuan dapat didalami dengan baik oleh para mahasiswa. Sekalipun mahasiswa telah mengikuti berbagai rangkaian penenilaian dan pengukuran, namun harus pula diketahui pemahaman secara operasional dalam suatu wujud nyata, oleh karena itu, weblog ini menyediakan juga Ujian A khir Semester (UAS) bagi para mahasiswa. K etiga proses evaluasi ini dipandang dapat mewakili kompetensi akhir mahasiswa sebagaimana yang tertera di dalam perencanaan pembelajaran semester. Dalam kaitannya dengan pembelajaran blended, ketiga proses ini, dapat pula dilakukan secara offline jika para pengguna menghadapi permasalahan jaringan Internet.

Penggabungan sumber belajar juga menunjukkan bahwa semua bahan seperti modul pembelajaran, buku teks, dan jurnal dapat diakses secara online dan dapat diterima secara langsung dari dosen pemandu mata kuliah atau di perpustakaan UIN Alauddin Makassar. Penggabungan pelaksanaan pembelajaran pun demikian. Jika perkuliahan disajikan secara online, peserta didik dapat melakukan diskusi online di antara mereka yang dipandu oleh dosen pembina mata kuliah, maka dalam pertemuan tatap muka, diskusi dapat dilakukan dalam ruang kelas tradisional sehingga bahan diskusinya memiliki materi yang sama. Penggabungan lain, dilakukan pada saat melakukan evaluasi 
pembelajaran di mana aspek yang menjadi penilaian standar adalah pemberian kuis setiap akhir pembahasan untuk setiap pokok bahasan, kemudian ujian tengah semester pada pertemuan kedelapan atau kesembilan untuk mengukur kemampuan peserta didik dari kumpulan pokok bahasan, dan diakhir dengan ujian akhir yang fokusnya pada penerapan teori dan konsep yang diperoleh selama perkuliahan.

Dalam pelaksanaan pembelajaran, weblog ini menyediakan dua sumber aktivitas, yaitu forum diskusi online dan menonton video pembelajaran. Forum diskusi online dilakukan dengan memberikan beberapa pertanyaan yang harus dijawab oleh peserta didik. Jawaban yang diberikan kemudian dijadikan sebagai bahan diskusi yang melibatkan respon dari peserta didik lain dan umpan balik dari dosen. Sedangkan video pembelajaran berisi bahan kajian yang melibatkan peserta didik untuk menganalisis, mengkaji, dan melaporkan kepada dosen untuk mendapatkan umpan balik.

Hasil Implementasi Pembelajaran Campuran Matakuliah Ulumul Qur'an

Dari berbagai literasi yang dikenal secara umum berkaitan dengan penerapan pembelajaran blended dapat berbeda antara satu perguruan tinggi dengan perguruan tinggi lainnya, tergantung dari karakteristik peserta didik, ketersediaan sarana dan prasarana, dan kompetensi tenaga pendidik sebagai pengembang pembelajaran. Demikian halnya dengan pembelajaran blended yang terdapat pada Universitas Islam Negeri (UIN) Alauddin $M$ akassar bernama B lended L earning $M$ ata Kuliah U lumul Q ur' an yang dapat diakses melalui link: quranimedia.uin-alauddin.ac.id.. Model ini pada awalnya dikembangkan pada mata kuliah Teknologi Pendidikan yang di ampuh oleh Prof. Dr. H. Azhar A rsyad, M.A. dengan Prof. Dr. M uhammad Y aumi, M.Hum., $M . A$. yang diberi nama BLASIU, kemudian dikembangkan juga pada mata kuliah Ulumul Quran yang dipandu oleh Prof. Dr. A chmad A bubakar, M.A.

Pada awalnya pelaksanaan perkuliahan yang dilakukan di Pascasarjana dilakukan secara face to facesaja tanpa ada kegiatan tambahan lain termasuk dalam pengelolaan sumber belajar. Itulah sebabnya, pembelajaran blended dengan memanfaatkan weblog yang dipadu dengan peralatan online lainnya dikembangkan untuk memfasilitasi pelaksanaan pembelajaran secara periodik di Pascasarjana. Dalam perkembangannya, pembelajaran blended semakin diminati oleh peserta didik baik dilakukan pada Pascasarjana maupun pada fakultas-fakultas yang ada di lingkungan UIN Alauddin Makassar. Itulah sebabnya weblog mata kuliah ulumul qur'an dirancang dan dikembangkan dengan 
memaksud untuk mewujudkan pembelajaran yang menggunakan basis media dan teknologi termasuk berbagai aplikasi yang sesuai dengan kondisi real UIN A lauddin M akassar.

Oleh karena itu, pada bagian ini peneliti membahas hasil implementasi pembelajaran blended dalam mata kuliah Ulumul Qur'an pada Pascasarjana UIN Alauddin Makassar. Untuk memudahkan pembahasan ini, penelitian mengkaji dari lima aspek penting yaitu (1) pemanfaatan aneka sumber, (2) partisipasi aktif, (3) konstruksi pengetahuan, (4) pemberian umpan balik, dan (5) peningkatan prestasi akademik. Secara bertahap, kelima aspek dapat dijabarkan berikut ini:

1. Peningkatan Pemanfaatan A neka Sumber B elajar

K ekayaan sumber belajar yang tersedia secara online memberikan kesempatan yang baik bagi peserta didik di dalam mengeksplor dan menambah bahan bacaan sehingga dapat mengerjakan tugas atau menjawab kuis, atau tugas-tugas tersetruktur dan tidak terstruktur yang dipersyaratkan dalam mata kuliah. U mpan balik menjadi bagian yang tak terpisahkan untuk mengarahkan kebenaran sumber dan ketepatan pemahaman dari perspektif mahasiswa.

Sebagai mahasiswa, kami dapat mengeksplor dan mengetahui lebih banyak lagi wadah belajar maupun perpustakaan online yang ada, seperti aplikasi IPUSNAS (perpustakaan digital persembahan Perpustakaan Nasional Republik Indonesia). Dengan melihat situasi pandemi saat ini, pengambilan keputusan melaksanakan pembelajaran model blended learning (Daring) saya rasa sangat efektif. Kegiatan dan tujuan pembelajaran tetap dapat tercapai walau dengan sistem daring. Model interaksi yang paling menarik dan baik saat ini menggunakan aplikasi WhatsA pp, yang mana aplikasi ini dapat menggunakan suara maupun catatan dan tentu lebih hemat dari aplikasi yang lain. Prospek penggunaan blended learning (Daring) bagi kemajuan dunia Pendidikan sangat baik. Tapi, tentu dengan pengkoordinasian dan sistem yang lebih siap termasuk penyediaan aneka sumber belajar untuk membangun kemudahan akses terhadap materi dan bahan ajar yang memadai (Nurlia, mahasiswa Prodi PB A 2, 10 M aret 2020).

Hasil implementasi pembelajaran blended memberi dampak signifikan terhadap peningkatan pemanfaatan sumber belajar yang dapat diperoleh baik melal ui buku-buku online, jurnal online, modul, dan berbagai sumber-sumber digital seperti audio, video, dan multimedia lainnya. Senada dengan pernyataan ini, sebagian mahasiswa lain juga memberi ketegasan bahwa 
Saat ini kita telah memasuki masa yang disebut sebagai Knowledge age sebagai abad pengetahuan, dengan berkembangnya pengetahuan, teknologi utama, kecenderungan pembelajaran masa depan telah mengubah pendekatan pembelajaran tradisional ke arah pembelajaran masa depan, seiring perkembangan kemajuan dunia pendidikan orang dapat belajar di mana saja artinya orang dapat belajar di mana saja dengan memanfaatkan aneka sumber belajar. B elajar tidak lagi bergantung pada guru atau dosen, dalam pengertian bukan lagi merupakan satu-satunya sumber, melainkan dapat mengukases sumber berupa video, audio, audio-visual, dan multimedia dari mana saja dan kapan saja (Fajar, mahasiswa Prodi PAI 2, 10 M aret 2020).

Melalui pembelajaran blended bahan pembelajaran semakin banyak bukan hanya diperoleh melalui bahan cetak, melainkan bahan non-cetak dan digital yang dapat diperoleh asecara online. Sumber belajar seperti ini, memberi kreativitas baru bagi peserta didik untuk mencari dengan menggunakan mesin pencari sumber

Blended learning ini mengenalkan kepada Mahasiswa bahwa belaiar tidak mesti dilaksanakan secara konvensional saia tetapi harus memadukan atau mengkombinasikan pembelajaran secara digital. M enurut saya sangat cocok dilaksanakan karena di tengah pandemi wabah Covid-19, mahasiswa mampu menerapkan pembelajaran Daring sehingga belajar bisa di Rumah atau di mana saja, tidak monoton harus belajar di kampus (A nhar B atara Syawal PAI 2, $10 \mathrm{M}$ aret 2020)

Pemaduan pembelajaran konvensional dengan pembelajaran secara digital yang dimaksud dalam pernyataan tersebut merupakan pemaduan sumber belajar yang sangat cocok dengan keadan dan kondisi bangsa yang dilanda Pandemi Covid19 seperti sekarang ini. Pembelajaran blended dapat meningkatkan pemanfaatan aneka sumber belajar terutama pembelajaran daring yang dapat mengakses sumber belajar kapan saja, di mana saja, dan dalam kondisi apa saja, tidak dibatasi oleh waktu dan ruang. Pembelajaran seperti ini sangat ideal untuk digunakan karena tanpa menanggalkan sumber-sumber konvensional seperti bahan cetak, juga dapat mengintegrasikan dengan sumber-sumber non-cetak yang diperoleh secara online melalui situs-situs tertentu.

2. Pelibatan Partisipasi A ktif

Pembelajaran blended menurut pernyatan di atas memberi kemudahan dalam membangun partisipasi aktif dari mahasiswa 
dan dosen karena ditunjang oleh berbagai aplikasi dan aneka sumber media dan teknologi yang digunakan. Semakin banyak dan sesuai dosen memanfaatkan media dan teknologi, semakin besar partisipasi mahasiswa dalam kegiatan pembelajaran, keaktifan dalam mengerjakan tugas, berdikusi kelompok, melaksanakan tugas membaca, melacak sumber merupakan ciri dari bentuk partisipasi yang dilakukan oleh peserta didik dalam pembelajaran. Itulah sebabnya informan menganggap bahwa pembelajaran daring dapat meningkatkan partisipasi dari mahasiswa, seperti dikatakan di bawah ini.

Penerapannya pembelajaran blended cukup baik, kita masih bisa bertatap muka saat kuliah meskipun lewat Daring. Pembelajaran tetap berlangsung sebagaimana mestinya. saya melihat cukup efektif karena dapat mengundang partisipasi aktif dari mahasiswa. Pihak kampus telah menyediakan Pembelajaran Blended Learning (Daring) yang bisa diakses oleh mahasiwa dan dosen. M eskipun dalam pembelajaran ini ditemukan beberapa kendala, namun pembelajaran Daring saya cukup efektif dikakukan oleh dosen dan mahasiswa. menurut saya model yang dipakai paling menarik dan baik adalah Video Comference dan A udio Recording. Media ini cukup membantu karena adanya penjelasan langsung oleh dosen terkait materi. Prospeknya sudah baik. Penggunaan Teknologi dalam hal ini pembelajaran Daring akan semakin meningkatkan kualitas dunia pendidikan. Pemanfaatan IT akan sangat membantu proses pembelajaran (Rabiah, mahasiswa Prodi PAI 2, $10 \mathrm{M}$ aret 2020).

Partisipasi yang dimaksud mencakup partisipasi aktif dalam mencari dan memanfaatkan sumber belajar yang tersedia, mengakses dan menonton video pembelajaran, membaca dan mengkaji sumber, membangun diskusi dengan teman kelas, serta aktif dalam mengisi dan menjawab kuis pada setiap akhir pembelajaran.

Dalam pembelajaran blended, terbangun interaksi antara mahasiswa dengan mahasiswa, dan dosen dan yang paling menarik menurut saya adalah interaksi yang mengunakan basis teknologi video dan audio (voice), seperti rekaman audio dan video. Interaksi seperti ini memberi kemudahan bagi mahasiswa dan dosen untuk membangung partisipasi secara aktif dalam pelaksanaan pembelajaran. Penggunaan blended learning juga efektif bagi kemajuan dunia pendidikan dan memiliki prospek yang cukup bagus. Jika pembelajaran model ini dilengkapi dengan aplikasi khusus di bawah naungan pemerintah. Dan alat dukung lainnya 
lebih dioptimalkan, seperti penyediaan jaringan dan quota seluruh pengguna (A bdil M ubarak Azis PBA 2, $10 \mathrm{M}$ aret 2020).

Indikator utama yang mendukung proses pembelajaran adalah adanya interaksi multi arah, antara mahasiswa yang satu dengan mahasiswa yang lain, antara mahasiswa dengan dosen, antara mahasiswa, dosen, dengan sumber belajar. Jika interaksi ini terbangun, maka pelibatan partisipasi aktif dari dosen dengan mahasiswa secara otomatis juga terbangun. Partisipasi aktif dalam belajar menjadi dasar yang sangat kuat dalam memberikan kontribusi dan memungkinkan penyajian materi dapat terserap dengan mudah dalam menambah khazanah pengetahuan.

Dalam penerapannya, kami hanya menggunakan dua media yang sudah bisa memenuhi kebutuhan dalam pembelajaran, yaitu video conference dan forum diskusi. Menyimak dan memberikan pendapat secara langsung serta mengefisienkan waktu pembelajaran. Penggunaan media harus dipergunakan sebaik-baiknya, namun interaksi social dan bertemu langsung pada saat pembelajaran itu lebih utama dengan mendapatkan beberapa faedah interaksi sosial dan keharmonisan antara mahasiswa dan dosen. Di sini pembelajaran online dapat peran dalam membangun partisipasi mahasiswa dan juga dosen dalam berbagai bentuk. Harapan kami dari metode daring ini, bisa dipergunakan pada hal atau situasi yang memang sangat diperlukan. Guna mengefisienkan waktu dan kondisi bagi mahasiswa dan dosen (Rizal, Prodi PAI 3, 10 M aret 2020).

Pernyataan tersebut menunjukkan bahwa interaksi sosial dalam pelaksanaan pembelajaran jauh lebih efektif dalam melibatkan mahasiswa dan dosen. Itulah sebabnya penggunaan media harus dipergunakan sebaik-baiknya agar dapat memperoleh beberapa faedah seperti interaksi sosial dan keharmonisan antara mahasiswa dan dosen. Pembelajaran online dalam hal ini peran untuk membangun partisipasi aktif antara mahasiswa dan juga dosen dalam berbagai bentuk

\section{Konstruksi Pengetahuan}

Pembelajaran blended dipercaya dapat memberikan kesempatan kepada mahasiswa untuk mengonstruk pengetahuan dari hasil interaksi dengan dosen, mahasiswa lain, dan sumber belajar. Pemaduan berbagai sumber belajar memungkinkan mahasiswa untuk selalu menambah wawasan pengetahuan dan meningkatkan keterampilan teknik dalam menggunakan dan mengoperasikan teknologi berbasis pada berbagai aplikasi yang digunakan. 
A dapun hasil implementasi pembelajaran B lended L earning untuk dosen dan mahasiswa, mengalami proses yang sangat baik dan berjalan sesuai rencana, sehingga implementasinya sangat berkaitan dengan penambah wawasan mahasiswa. Sejauh ini saya melihat efektifitas pembelajaran model blended learning daring yang diterapkan untuk dosen dan mahasiswa, bisa dikata masih berjalan belum stabil baik itu kendala jaringan maupun akses referensi sangat minim, dikarenakan beberapa hal diantaranya akses buku dan yang kedua factor tempat kondisi yang sangat tidak memungkinkan untuk mengakses internet. Namun, pembelajaran ini sangat efektif dalam peningkatan wawasan dan pengetahuan peserta didik (A swan A sri, Mahasiswa Prodi PAI 2, 10 M aret, 2020)

Selain meningkatkan menambah wawasan mahasiswa, juga dapart meningkatkan daya nalar, pembelajaran blended khususnya yang disajikan secara online dipercaya dapat meningkatkan keaktifan atau intensitas kegiatan belajar secara terus-menerus dan daya tahan yang lama. Begitu pula pembelajaran blended dipandang berkontribusi positif dalam menambah wawasan bagi peserta didik.

Hasil pembelajaran blended yang saya ikuti melalui mata kuliah ini cukup memuaskan, karena tetap menjalankan proses perkuliahan secara tatap muka melalui vidio conference atau zoom sehingga hasil materi yang disampaikan tetap tersalurkan dengan baik, di lain hal menambah wawasan terkait penggunaan berbagai macam media pembelajaran (tekhnologi) secara daring. dalam penerapannya cukup efektif, hanya saja masih terdapat beberapa hambatan yang dihadapi selama proses kuliah daring sehingga materi yang disampaiakan kurang memuaskan bagi beberapa mahasiswa yang memiliki kendala. Dalam penerapannya saya lebih tertarik menggunakan via teleconference dan zoom meeting, blended learning sangat mendukung kemampuan dalam meningkatkan wawasannya terkait dengan pemahaman konsep dan penggunaan tekhnologi berbasis komputer atau android, dan juga memudahkan bagi para pengajar untuk tetap melaksanakan pembelajaran tanpa tatap muka secara langsung, sehingga penarapannya perlu diadakan pada tiap satuan pendidikan guna kemajuan dunia pendidikan (A ulia, mahasiswa Prodi PBA 2, 10 M aret 2020).

Harus diakui bahwa ketercapaian tujuan pembelajaran bukan hanya berlandaskan pada penguasaan konten semata, 
melainkan juga penguasaan terhadap prosedur penerapan dari suatu konsep atau teori. Dengan menggunakan beberapa media dan teknologi berbasis aplikasi pengetahuan prosedural mahasiswa dapat berkembang dengan baik, walaupun disadari juga terdapat berbagai kendala secara internal tentang jaringan Internet dan jaringan listrik yang kurang stabil. Hal ini juga ditunjang dengan penggunaan media pembelajaran dan proses pembelajaran yang tidak monoton, tetapi diberikan dengan variasi yang sesuai dengan tingkat pengetahuan dan wawasan mahasiswa itu sendiri. Sejalan dengan pernyataan di atas, pembelajaran blended juga diyakini dapat meningkatkan penguasaan keterampilan teknik melalui penggunaan beragam media dan aplikasi teknologi, seperti dikatakan dalam pernyataan di bawah ini.

Memudahkan mahasiswa mengerjakan tugas tanpa harus bertatap muka langsung dengan dosen. Dosen dan mahasiswa sama-sama belajar menggunakan aplikasi agar lebih memahami. Cukup efektif namun kembali lagi pada perkara utama yakni jaringan yang kadang kurang bersahabat. Mahasiswa pun tidak bisa datang langsung ke perpustakaan untuk mencari referensi tugas. Seperti normalnya mahasiswa dan dosen bertatap langsung dalam ruangan kelas karena model tersebut melahirkan keakraban antara dosen dan mahasiswa serta mahasiswa satu dengan yang lain. Mahasiswa secara mandiri memegang kendali atas keberhasilan belajar. Bebas menentukan kapan akan menyelesaikan tugas dan bagian mana dalam satu modul yang ingin dipelajarinya terlebih dahulu. Dan untuk dosen bisa jadi pedoman jika sedang berhalangan masuk kelas (Ety, mahasiswa Prodi PAI 2, 10 M aret 2020).

Pernyataan tersebut menunjukkan bahwa pembelajaran blended sangat memungkinkan untuk terbangunnya kemampuan untuk mengatur dirinya sendiri (self-regulation) atau seperti dikatakan sebagai mahasiswa secara mandiri memegang kendali terhadap apa yang dilakukan untuk mengembangkan dirinya, seperti belajar sendiri, mengerjakan tugas sendiri, dan menentukan hasil belajar sendiri. $\mathrm{Hal}$ ini penting agar mahasiswa mandiri dalam segala hal termasuk dalam mencari referensi sendiri, belajar sendiri, merefleksi sendiri sehingga mengetahui tentang perkembangan dan kemajuan dirinya jika dibandingkan dengan peserta didik yang lain.

Hasil implementasi pembelajaran blended (untuk dosen dan mahasiswa) sampai sekarang ini cukup memuaskan karena mempermudah proses pembelajaran jarak jauh. Terkait 
efektitifitas yang diterapkan saat ini menurut saya sudah lumayan efektif. Cuma yang menjadi kendala pembelajaran di sini ialah salah-satunya jaringan yang dapat menghambat proses pembelajaran model blended learning (Daring) sejauh ini. Model interaksi yang paling menarik dan baik digunakan menurut saya ialah dengan dilakukan pembelajaran dengan menata lingkungan yang ada sebagai sumber belajar dengan menyediakan sumber-sumber belajar yang memadai. (Fajar, mahasiswa Prodi PAI 2, 10 Maret 2020).

Pembelajaran blended dalam perspektif ini dipandang dapat mempermudah proses pembelajaran sehingga efektivitas proses pembelajaran dapat mendukung suasana pembelajaran yang menyenangkan dan memberi kepuasan tersendiri bagi mahasiswa. A rtinya, pembelajaran blended menarik perhatian, membangkitkan gairah belajar, meningkatkan pemahaman konsep, dan memberi kepercayaan diri kepada mahasiswa untuk berbicara, sharing pendapat, dan menunjukkan hasil dan prestasi yang dicapai. Dengan demikian blended learning di sini memberi dampak pada peningkatan pemahaman konsep tentang ilmu pengetahuan.Bukan hanya itu, pembelajaran blended memberi kemudahan dalam mengupdate pengetahuan seiring dengan perkembangan yang begitu cepat, seperti dijelaskan dalam pernyataan informan di bawah ini.

Hasil implementasi cukup memuaskan untuk kondisi seperti sekarang ketimbang libur begitu saja dan tidak ada proses belajar yang terjadi. Tingkat efektifitas cukup baik karena mahasiswa dapat mengenal konsep-konsep yang berkembang secara cepat dalam masyarakat, pengetahuan selalu terupdate dalam waktu yang sangat cepat sekali. Model daring ini sudah sangat cocok dalam situasi sekarang. prospek kedepan boleh digunakan dalam hal-hal tertentu dan kondisi tertentu sebab tentu bertemu lansung lebih baik dan tidak akan bertemu dengan masalah seperti jaringan lelet dan lain sebagainya (I rfan, mahasiswa Prodi PAI 3, 10 M aret 2020).

Selain meningkatkan pemahaman konseptual tentang suatu bidang ilmu yang sedang dipelajari, pembelajaran blended juga menyediakan ruang yang sangat terbuka untuk mengupdate atau memperbarui ilmu pengetahuan terbaru. Perkembangan informasi dan teknologi yang begitu cepat menyebabkan kita aktif untuk mengkaji dan mengejar sebaran ilmu pengetahuan terbaru. M elalui pembelajaran blended mahasiswa dan dosen memperoleh 
pengetahuan terbaru dalam waktu yang sangat cepat dengan cara yang tepat.

A lhamdulillah kami sebagai mahasiswa sangat bersyukur bisa belajar daring karena dapat memperoleh pengetahuan baru dan memupuk nalar akademik mahasiswa. Pembelajaran blended dapat menyelesaikan beberapa materi dengan baik, dengan berbagai macam bentuk tugas dari bapak Dosen, pembelajaran daring menjadikan kami aktif, baik dalam mengerjakan tugas maupun dalam mencermati isi-isi pokok materi yang disampaikan Bapak Dosen baik dalam bentuk rekaman video maupun hanya audio saja. Oleh karena itu, selain memeroleh pengetahuan baru juga kami dapat mengembangkan daya nalar dalam mengkajia dan memabca berbagai peristiwa dalam pembelajaran (Ade, mahasiswa prodi PAI 2, $10 \mathrm{M}$ aret 2020).

Peningkatan daya nalar memang menjadi indikator utama ketika pembelajaran yang melibatkan berbagai sumber dan penerapan model pembelajaran berbasis pada kegiatan yang menumpan pemikirian kritis mahasiswa. Peningkatan daya nalar juga didukung dengan pemanfaatan berbagai aplikasi yang mengharus mahasiswa untuk ikut terlibat dalam membaca, menganalisis, mensintesis dengan membandingkan antara berbagai sumber yang tersedia. M engupdate pengetahuan berdasarkan sumber-sumber yang terbaru merupakan ciri perkembangan ilmu pengetahuan dari waktu-ke waktu sebagai hasil temuan ilmuan yang dipublikasikan secara global dalam jurnal-jurnal internasional. Optimalisasi pemanfaatan sumbersumber tersebut dapat memicu terbangunnya keinginan kuat untuk selalu mencari dan mendapatkan sumber-sumber mutakhir. $\mathrm{Hal}$ ini diperkuat dengan pandangan sebagai mahasiswa yang melihat efektivitas pembelajaran blended dari perspektif pengupdatan ilmu pengetahuan.

Blended learning sangat efektif dalam meningkatkan kreativitas untuk mencari sumber-sumber ilmu terbaru. Kami sebagai mahasiswa diharapkan mengoptimalkan segala wadah yang tersedia dalam menambah wawasan mahasiswa berkaitan dengan materi perkuliahan. Pembelajaran model blended learning, dapat dikatakan kurang efektif, dibandingkan dengan dengan pembelajaran tatap muka dalam kelas. Tetapi khusus untuk kekakayaan sumber terbaru sangat memadai. Dengan mempertimbangkan pandemi yang marak saat ini, maka pembelajaran model daring ini cukup efektif dalam pelaksanaan proses pembelajaran sebagai solusi dalam 
pelaksanaan pembelajaran tatap muka yang cenderung menggunakan referensi klasik (lama). Y ang paling menarik dan baik digunakan adalah interaksi yang mengunakan voice. penggunaan blended learning (Daring) ini tentunya mempunyai nilai positif bagi kemajuan dunia Pendidikan. akan tetapi model pembelajaran daring ini akan lebih efektif apabila dilengkapi dengan aplikasi/alat dukung lainnya yang lebih optimal seperti penyediaan jaringan dan quota seluruh pengguna (Randy, mahasiswa Prodi PBA 2, $10 \mathrm{M}$ aret 2020).

Sangat jelas dalam pernyataan tersebut, bahwa sekalipun diakui bahwa pembelajaran blended dari segi interaksi langsung dengan dosen sangat tidak efektif, tetapi dilihat dari pemanfaatan multi sumber pembelajaran, pembelajaran ini menjadi solusi terhadap kesulitan sebagaian mahasiswa dalam mendapatkan referensi yang banyak dan terbaru

4. Pemberian Umpan Balik

M odel interaksi yang terbangun dalam pembelajaran blended sangat cocok dengan keadaan peserta didik sehingga memudahkan bagi dosen untuk memberikan umpan balik (feedback) terhadap partisipasi peserta didik. Artinya, pembelajaran yang melibatkan interaksi peserta didik mendukung terlaksananya proses pemberian umpan balik kepada mahasiswa, seperti dikatakan dalam pernyataan berikut ini.

Pembelajaran blended dalam meningkatkan keaktifan mahasiswa dalam memperoleh ilmu yang terbarukan sehingga dapat menambah wawasan dan pengetahuan mahasiswa khususnya dalam bidang IT. Pembelajaran Blended Learning (Daring) untuk beberapa kegiatan perkuliahan lebih efektif karena dapat memperoleh sistem umpan balik yang diberikan oleh dosen. Meskipun demikian, kondisi pandemi seperti sekarang, perkuliahan Daring adalah solusi terbaik. M enurut saya, interaksi yang paling menarik adalah video conference jika jaringan mendukung karena setelah selesai menonton, umpan balik pun diberikan oleh dosen. Dan yang paling baik dan nyaman adalah voice. Sangat baik, jika ditunjang dengan fasilitas yang memadai, dengan Daring kita dapat menghadiri seminar internasional, dan dapat mencari referensi yang lebih Iuas (M ujahidin Alhaq, mahasiswa Prodi PAI 3, 10 $M$ aret 2020).

Pemberian umpan balik pada dasarnya dapat memberi penguatan pemahaman kepada peserta didik sekaligus juga untuk mengoreksi dan mengarahkan kemampuan mereka. Pembelajaran 
blended dipandang sangat efektif karena mendorong sistem umpan balik baik dilakukan secara lisan maun dikembangkan secara tertulis melalui perbaikan makalah dan perbaikan nilai dalam proses pelaksanaan evaluasi. Seain itu, umpan balik dapat dilakukan juga dengan pembelajaran berbasis pada video conference karena dapat dilakukan secara sinkronus kepada peserta didik.

Model yang paling menarik dan cocok bagi saya adalah tatap muka online (Video Conference) dan Diskusi Online. $K$ arena kedua model ini efektif dalam proses pembelajaran. Prospek penggunaan model daring ini sudah sangat baik dilaksanakan di lingkungan kampus karena memberikan feedback (umpan balik) yang baik antara dosen dan Mahasiswa (A nhar B atara Syawal PAI 2, 10 M aret 2020)

U mpan balik adalah salah satu varian yang sangat penting dalam memberikan kesempatan kepada peserta didik dalam memberbaik kekeliruan yang dilakukannya baik yang berkenaan dengan konsep, maupun dalam hubungannya dengan penerapan dan pengaplikasian dari konsep tersebut. Salah satu bentuk interaksi yang dilakukan antara dosen atau pendidik dengan mahasiswa adalah terjalinnya komunikasi yang baik termasuk dalam memberikan umpan balik karena sulit bagi mahasiswa untuk memahami kebenaran dari apa yang dikembangkan tanpa pemberian umpan balik tersebut, seperti pernyataan berikut ini.

Hasil implementasi pembelajaran Blended L earning, bisa dibilang sangat baik. Karena dengan pembelajaran ini, kami mahasiswa dituntut tetap optimal dapat belajar dari banyak sumber agar mampu menjawab pertanyaan yang diberikan, begitu pula bagi dosen memungkinkan untuk memberikan umpan balik dari yang yang kami kerjakan sehingga kami dapat memahami secara mendalam. (Nurlia, mahasiswa Prodi PBA 2, 10 M aret 2020).

Umpan balik yang diperoleh mahasiswa dari dosennya memberi kesempatan bagi mahasiswa untuk mengulangi pembelajaran ini dengan mengakses sumber yang direkomendasikan sehingga berdampak pada peningkatan kemampuan dan keterampilan teknik seperti dengan menggunakan aplikasi yang sesuai untuk menyelesaikan tugastugas yang diwajibkan. A plikasi yang dimaksud berkaitan dengan jenis tugas seperti merekam suara, memposting video presentasi, atau menganalisis ayat-ayat al-Qur'an melalui aplikasi-aplikasi tertentu.

Pembelajaran daring sangat bermanfaat bagi saya sebagai mahasiswa dan bagi Dosen karena Dosen dapat memberikan 
pembelajaran melalui media virtual maupun modul, kemudian dilanjutkan dengan penugasan dan pemberian umpan balik dengan memeriksa tugas-tugas tersebut kemudian dikembalikan kepada mahasiswa dalam waktu yang di tentukan dengan menggunakan aplikasi yang sesuai dengan kemampuan peserta didik. Sistem pembelajaran daring memberikan manfaat yang luar biasa karena sebagai mahasiswa dapat mengulang-ulang pembelajaran tanpa membuat dosen lelah (A de, mahasiswa prodi PAI 2, 10 M aret 2020).

Pemberian umpan balik merupakan dasar yang kuat untuk membuka wawasan berpikir, mengembangkan pemahaman mendalam, daya nalar dan memperbaiki keterampilan teknik. Semua aspek ini dapat tercipta melal ui pembelajaran blended baik yang dilakukan secara tatap muka, maupun melalui pembelajaran yang berbasis pada weblog seperti dalam pembelajaran ulumul qur'an ini

\section{Peningkatan Prestasi A kademik}

Prestasi akademi mahasiswa merupakan hasil dari proses pembelajaran yang melibatkan aneka sumber belajar, pemanfaatan media, teknologi, dan aplikasi yang sesuai dengan kebutuhan peserta didik, serta melibatkan partisipasi dan interaksi multi arah peningkatan prestasi akademik. Pembelajaran blended dalam mata kuliah ulumul qur' an dipandang dapat meningkatkan prestasi akademik mahasiswa baik ditinjau dari data kualtiatif yang dikumpulkan melalui wawancara maupun data uang dikumpulkan secara kuantitatif melalui analisis terhadap penilaian yang dilakukan oleh dosen pemandu mata kuliah.

Secara pribadi saya merasa senang belajar di aplikasi L entera dan weblog karena pada aplikasi ini, semua jadwal dan materi yang akan di laksanakan dalam setiap pertemuan sudah tersusun rapi dengan jadwal dan waktu yang telah ditentukan. Dari segi prestasi akademik, saya sendiri mendapat penilaian yang semakin bagus dari dosen pemandu mata kuliah karena cenderung membaik dari waktu ke waktu. Oleh karena itu prospek pembelajaran daring sangat bagus dapat memperlancar pelaksanaan pembelajaran dengan efektif tentunya dengan dukungan kuota internet yang memadai tetapi bagi saya sebagai seorang mahasiswa tidak efektif dalam sebuah diskusi karena mahasiswa tidak bisa mengekspresikan sebuah kajian yang didiskusikan. Walaupun demikian, jika seluruh sumber dapat dimanfaatkan saya rasa prestasi akademik 
mahasiswa cenderung semakin baik (A de, mahasiswa prodi PAI 2, $10 \mathrm{M}$ aret 2020).

Saat ini, berbagai kendala dalam mengukur mengukur perkembangan prestasi akademik mahasiswa karena sistem perkuliahan yang banyak hambatan dari segi jaringan Internet. N amun pada umumnya, nilai mahasi swa hampir sama saja dengan nilai yang diperoleh sebelum masa Pandemi COVID-19. Tetapi pernyataan mahasiswa menunjukkan bahwa terdapat peningkatan prestasi akademik yang terjadi dari waktu ke waktu sekalipun menghadapi proses pembelajaran yang sedikit kurang normaol.

Efektifitas dari penerapan pembelajaran Blended ini sangat efektif sekali, karena kapanpun dan dimanapun kita bisa berkomunikasi dengan dosen, untuk melakukan proses belajar mengajar/perkuliahan dengan via Whatsapp, video online, dan conference. Jika ditanyakan tentang prestasi akademik, maka saya mendapatkan nilai pada semester ini lebih baik dari nilai yang saya peroleh sebelumnya, yaitu sebelum masa Pandemi. Teman-teman kelas saya juga mengatakan demikian, artinya alhamdulillah pembelajaran ponline di masa Pandemi membawa kebanggaan tersendiri. Saat ini harus diakui bahwa dengan adanya pembelajaran daring ini memudahkan bagi kami sebagai mahasiswa untuk berkomunikasi dengan dosen mata kuliah Ulumul Qur'an. dan bentuk implementasi dengan menggunakan model ini, kami sangat semangat untuk mengerjakan tugas dari dosen dan proaktif dalam pembelajaran. Hemat saya, kolaborasi antara dosen dan mahasiswa dalam pembelajaran ini sangat bagus (Nurhidayah, mahasiswa Prodi PAI 2, 10 J uni 2020).

Prestasi akademik yang dimaksud di sini bukan hanya berkenaan dengan nilai atau skor yang mereka dapatkan pada setiap mengisi kuis, melaksanakan diskusi online, ujian tengah semester, atau ujian akhir semester, melainkan lebih besar dari itu termasuk pengetahuan dan keterampilan untuk mengakses sumber- sumber belajar, keterampilan menggunakan teknologi dalam pembelajaran, dan budaya akademik lain seperti menulis makalah dengan prinsip-prinsip yang dijalankan berdasarkan aturan mengutip, mebuat referensi dengan aplikasi-aplikasi seperti mendeley dan lain-lain, seperti pernyataan berikut ini.

Menurut saya, prestasi akademik tidak hanya yang berkaitan dengan nilai akhir yang diperoleh dari dosen, tetapi yang lebih penting adalah bagaimana kita memahami penggunaan teknologi termasuk dalam hubungannya dengan penulisan makalah dengan berbagai software yang tersedia. Terus-terang saya merasakan adanya peningkatan 
prestasi dalam hubungannya dengan menulis karya tulis ilmiah. Kalau dalam pembelajaran, aplikasi yang bagus di gunakan dalam Media pembelajaran adalah Hangout meet selain M odelnya sama dengan zoom, aplikasi ini memang di sediakan untuk media pembelajaran sehingga Dosen bisa lansung mengabsen kehadiran mahasiswa dengan otomatis dan beberapa keunggulan lain, dan penggunaan Data lebih hemat. Tentus saja K eadaan sekarang pada masa mendatang perkuliahan secara daring sangat berperan aktif dalam menunjang perkuliahan, maka sudah seharusnya setiap Dosen dan Mahasiswa di bekali perangkat, silabus dan teknik dalam pembelajaran daring (U mar, mahasiswa Prodi PAI 2, 10 J uni 2020).

Pernyataan ini memberi penekanan bahwa peningkatan prestasi akademik tidak harus dilihat dari skor atau nilai yang diperoleh, kualitas proses untuk mendapatkan hasil yang berkualitas juga menjadi indikator kunci dalam menerjemahkan apa yang disebut dengan prestasi akademik. Walaupun demikian, tidak dapat dipungkiri bahwa sebagian besar mahasiswa memahami prestasi akademik hanya yang berkenaan dengan nilai atau skor yang secara legal formal diberikan dan dilaporkan oleh dosen sebagai nilai akhir mahasiswa. Oleh karena itu, dalam penelitian ini juga, nilai atau skor itu dapat dilihat sebagai berikut:

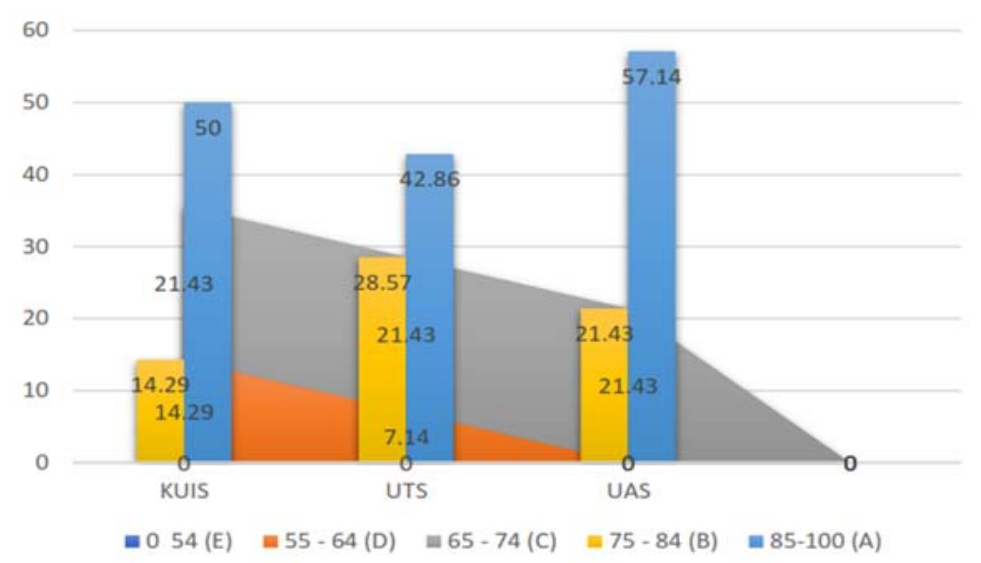

Gambar 1. Skor Mata Kuliah Ulumul Qur'an 2019

Pada bagan kombo di atas, menunjukkan bahwa terdapat skor 7 (50\%) orang dari 14 (100\%) orang yang mendapat nilai A 
pada kuis, $6(42.86 \%)$ orang pada UTS, dan 8 (87.14) orang pada UAS, artinya yang mendapat nilai tertinggi. Sedangkan yang mendapat nilai terrendah atau mendapat nilai $D$ sebanyak 2 (14.29\%) pada Kuis, 1 (7.14\%) pada UTS, dan 0 pada UAS. Nilai yang tertera pada bagan di atas bukanlah nilai akhir yang dicapai oleh mahasiswa pada semester, melainkan nilai yang terkumpul dari tiga aspek yang di nilai, yaitu Kuis, UTS, dan UAS. Nilainilai lain seperti hasil diskusi online, tugas makalah, dan nilai partisipasinya tidak tercantum dalam bagan tersebut.

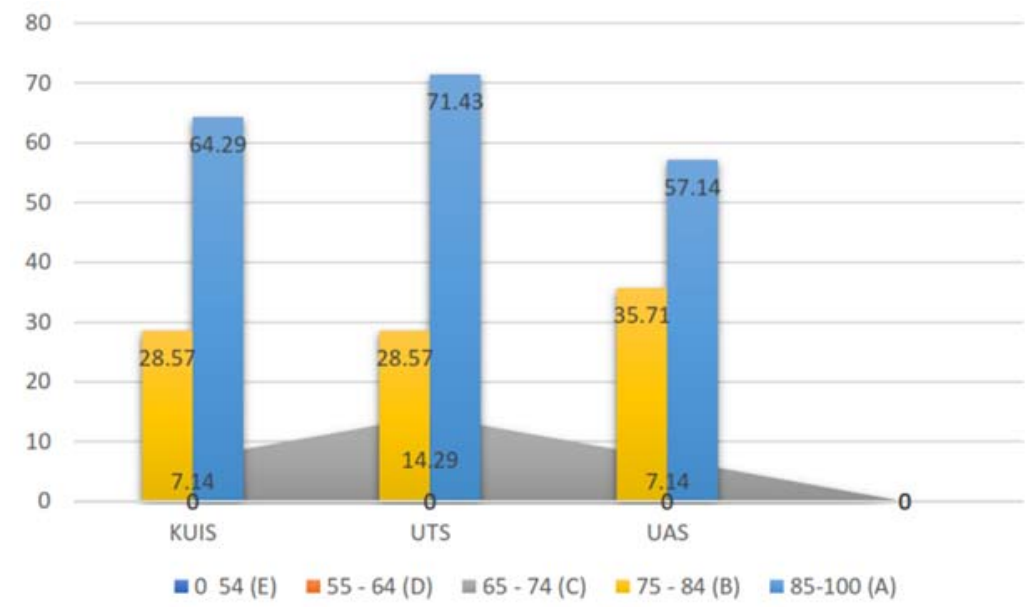

Gambar 2. Skor Mata Kuliah Ulumul Qur'an 2019

Pada bagan kombo yang terdapat dalam gambar 2 menunjukkan bahwa terdapat skor 9 (64\%) orang dari 14 (100\%) orang yang mendapat nilai A pada kuis, 10 (71.43\%) orang pada UTS, dan 8 (87.14) orang pada UAS yang mendapat nilai tertinggi (A). Sedangkan yang mendapat nilai terrendah atau mendapat nilai C sebanyak 1 (7.14\%) pada K uis, 2 (14.29\%) pada UTS, dan 1 (7.14\%) pada UAS. Artinya, mahasiswa yang mengambil mata kuliah U lumul Qur' an pada tahun 2020 tidak ada yang mendapat nilai E dan D untuk nilai Kuis, UTS, dan UAS. $\mathrm{Hal}$ ini dapat dikatakan bahwa terjadi peningkatan prestasi akademik mahasiswa yang belajar dengan menggunakan blended learning lebih banyak (80\%) disajikan melalui pembelajaran 
daring dibandingkan dengan blended learning yang mendapat kesempatan online sebanyak $40 \%$. Jika dibanding rata-rata nilai tertinggi untuk ketiga aspek (Kuis, UTS, dan UAS), maka diperoleh kenaikan rata-rata sebanyak 2 (14.29\%). Tetapi jika diambil dari nilai terrendah maka diperoleh hasil 3 (21.43\%). Sekalipun kenaikan tidak terlalu besar, tetapi peningkatan tersebut menggambarkan bahwa semakin tinggi penggunaan media dan teknologi dalam pembelajaran online, semakin besar nilai prestasi akademik mahasiswa yang dicapai.

\section{PENUTUP}

Hasil Implementasi Pembelajaran Blended Pada Mata K uliah Ulumul Q ur' an T ergambar Dari Lima A spek U tama, Y aitu (A) Peningkatan Pemanfaatan A neka Sumber, (B) Peningkatan Partisipasi Aktif, (C) Peningkatan Kemampuan Untuk M engonstruksi Pengetahuan, (D) Pengaktifan U mpan Balik, Dan (E) Peningkatan Prestasi A kademik. Peningkatan Pemanfaatan A neka Sumber Telah M endorong Peserta Didik Untuk Mampu $M$ engeksplor Dan M enambah B ahan B acaan, M engerjakan T ugas, Menjawab Kuis, Penggunaan Berbagai Aplikasi Dan Aneka Sumber Media Dan Teknologi. Semakin Banyak Dan Sesuai Dosen Memanfaatkan Media Dan Teknologi, Semakin Besar Partisipasi M ahasiswa Dalam K egiatan Pembelajaran, Keaktifan Dalam M engerjakan Tugas, B erdikusi K elompok, M elaksanakan Tugas M embaca, Dan M elacak. Peningkatan K emampuan Untuk Mengonstruksi Pengetahuan Dimulai Dengan Pengetahuan Faktual, Konseptual, Prosedural, Peningkatan Daya Nalar, Peningkatan U paya Untuk M engejar IImu Terbaru, K eterampilan Teknik Dan Kemampuan Untuk Mengatur Diri Sendiri (SelfRegulation). Perbaikan Untuk Pengaktifan Umpan Balik Tergambar Dari, Perbaikan M akalah, Pengembalian Tugas, K uis, Dan Perbaikan Beberapa Kesalahan Dari Uts Dan Uas. Peningkatan Prestasi A kademik Tergambar Dari Rata-R ata Nilai Tertinggi Untuk K etiga A spek (K uis, Uts, Dan Uas), Diperoleh Kenaikan Sebanyak 2 (14.29\%). Dilihat Dari Nilai Angkah Terrendah, Diperoleh Peningkatan Hasil Sebesar 3 (21.43\%). 
Sekalipun Kenaikan Tidak Terlalu Besar, Tetapi Peningkatan Tersebut Menggambarkan Bahwa Semakin Tinggi Penggunaan Media Dan Teknologi Dalam Pembelajaran Online, Semakin B esar Nilai Prestasi A kademik M ahasiswa Y ang Dicapai.

Penelitian ini masih jauh dari sempurna dari aspek evaluasi dan faktor-faktor pendukung dalam mencapai hasil pembelajaran campuran yang ideal.

\section{DAFTAR PUSTAKA}

Creswell, John W. Research Design Pendekatan Kaulitatif, K uantitatif, Dan M ixed. Y ogyakarta: Pustaka Pelajar, 2009.

Hooft, Y.-M. LinM. Van't. "The Impact of Blogs on Student Perceptions toward Social Interaction and Learning Satisfaction in Blended L earning." International Conference on Computers in Education (2008): 833-839. https://www.semanticscholar.org/paper/T he-Impact-of-

B logs-on-Student-Perceptions-toward-LinaH ooftb/0c185ff138b9ed415768b4deb2c3bf2732b1f86døtin g-papers.

Ibrahim, Nurdin. "Hubungan Antara Belajar Mandiri Dan Motivasi Berprestasi Dengan Hasil Belajar Pendidikan A gama Islam Di SM P Terbuka." Lentera Pendidikan 15, no. 1 (2012): 1-17.

M anrique, Cecilia, and Gabriel M anrique. "Leveraging Learning Resources: Social Networking, Online Teaching Utilities, Digital Media And The Modern Classroom Experience." International Journal of Arts \& Sciences 4, no. 21 (2011): 215-222.

Moleong, Lexi J. Metodologi Penelitian Kualitatif. XXVII. B andung: Remada Rosdakarya, 2010.

Rennie, Frank. "The Use of Flexible Learning Resources for Geographically Distributed Rural Students." Journal of Distance Education 24, no. 1 (2003). 
Retnaningsih, Rahayu. "E-Learning System Sebuah Solusi Pragmatis Program Vokasional Semasa Pandemi COVID19." Jurnal Taman Vokasi 8, no. 1 (2020): 28-34.

$Y$ aumi, M uhammad, and M uljono Damopolii. "Desain Blended Learning: Model Pemaduan Sumber Belajar Online Dan Tradisional." In Konferensi Nasional Ke- 6 A sosiasi Program Pascasarjana Perguruan Tinggi M uhammadiyah 'A isyiyah, 135-145. Y ogyakarta: Program Pascasarjana Universitas Muhammadiyah Yogyakarta, 2017. http://repositori.uinalauddin.ac.id/14929/. 